\title{
Dangerous sweets: severe hypokalemia with rhabdomyolysis and tetraparesis from chronic consumption of licorice
}

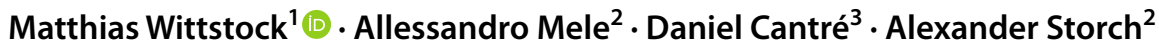

Received: 1 November 2020 / Revised: 27 November 2020 / Accepted: 4 December 2020 / Published online: 19 December 2020

(c) The Author(s) 2020

\section{Dear Sirs,}

Recently, Edelman and colleagues ${ }^{1}$ reported the case of a 44-year-old man with pseudohyperaldosteronism suggestive of excessive licorice consumption complicated by cardiac arrest associated with ventricular fibrillation. Beside these severe cardiac complications, acute non-traumatic tetraparesis may be observed as a symptom of severe hypokalemia due to liquorice consumption.

A 67-year-old female was admitted with an acute, nontraumatic, painless tetraparesis. Neurological exam revealed slight dysarthria, but no facial or bulbar weakness, a moderate tetraparesis (MRC level 3 in the lower limbs and MRC level 4 in the upper limbs) with only slightly weakened deep tendon reflexes. No sensory level could be shown. Upon admission, there was nausea with vomiting, a pathologically increased blood glucose level and bradycardia. Cranio-cervical computed tomography showed normal findings. The ECG did not show a prominent $U$ wave. The admission laboratory showed severe hypokalemia $(1.7 \mathrm{mmol} / \mathrm{l})$ and rhabdomyolysis with a serum creatine kinase of $2372 \mathrm{U} / 1$ (Table 1). No causes for an infectious or drug-induced hypokalemia could be determined. Nephropathy and a mass of the adrenal cortex were excluded by ultrasound. There was no laboratory evidence of metabolic-endocrine disorders such as primary and secondary hyperaldosteronism or hypercortisolism. We observed pathologically low levels of aldosterone ( $67 \mathrm{pmol} / \mathrm{l}$,

Matthias Wittstock

matthias.wittstock@med.uni-rostock.de

1 Department of Neurology, University Medicine Centre Rostock, University of Rockstock, Gehlsheimer Str. 20, 18147 Rostock, Germany

2 Department of Diagnostic and Interventional Radiology, University Medical Centre Rostock, University of Rockstock, Rockstock, Germany

3 Department of Pediatric Radiology and Neuroradiology, University Medical Centre Rostock, University of Rockstock, Rockstock, Germany normal range: $69-634 \mathrm{pmol} / \mathrm{liter})$ and renin $(1.5 \mathrm{pg} / \mathrm{ml}$, normal range: 3-22) with borderline elevated cortisol levels (601 nmol/liter, normal range: 133-537). Further exploration of the patient revealed a daily consumption of unusually high amounts of sweets containing liquorice (approx. $250 \mathrm{~g}$, corresponding to approx. $7.5 \mathrm{mg}$ of contained liquorice). A regression of the paresis was already evident $72 \mathrm{~h}$ after parenteral potassium substitution. The delayed increase of $\mathrm{CK}$ levels underlines the most probable mechanism of liquorice caused hypokalemia inducing vasoconstriction with relative ischemia in the active muscles leading to subsequent necrosis and rhabdomyolysis. The patient could be discharged without any neurological sequelae.

The substance glycyrrhizin contained in licorice is an inhibitor of the enzyme $11 \beta$-hydroxysteroid dehydrogenase being responsible for inactivating cortisol by converting it into cortisone. The total amount of glycyrrhizin is very variable in the different liquorice mixtures. The exact content in our patient's mixture was not declared. Due to the mineralocorticoid effect of cortisol on the aldosterone receptors, our patient shows the typical laboratory constellation of pseudohyperaldosteronism. ${ }^{2}$ This hypokalemic metabolic condition may be differentiated from Liddle, Bartter or Gitelman syndrome by blood pressure, age of onset, biochemistry***** and negative family history. ${ }^{3}$ Rhabdomyelysis or neurological deficits have been reported occasionally. ${ }^{4}$ Remarkably, already relatively small amounts of liquorice in our patient compared with reported cases $(<10 \mathrm{mg} \text { vs. } 300 \mathrm{~g} \text { daily })^{5}$ may lead to severe consecutive neurological deficits. This case illustrates the range of possible cardiologic and neurological problems due to hypokalemia and emphasizes the importance of a detailed anamnesis with a special focus on the eating habits of patients showing dyselectrolytemia and neurological deficits. 
Table 1 Laboratory data

\begin{tabular}{|c|c|c|c|c|c|c|c|}
\hline Laboratory value & $\begin{array}{l}\text { Reference } \\
\text { range, } \\
\text { adults }\end{array}$ & $\begin{array}{l}\text { Hospital admission } \\
25.04 .2020(13: 30)\end{array}$ & $\begin{array}{l}25.04 .2020 \\
(19: 30)\end{array}$ & $\begin{array}{l}26.04 .2020 \\
(8: 30)\end{array}$ & $\begin{array}{l}27.04 .2020 \\
(7: 15)\end{array}$ & $\begin{array}{l}27.04 .2020 \\
(14: 30)\end{array}$ & $\begin{array}{l}\text { Hospital discharge } \\
\text { on } 29.04 .2020 \\
(7: 30)\end{array}$ \\
\hline \multicolumn{8}{|l|}{ Blood } \\
\hline Sodium (mmol/liter) & $136-144$ & 137 & 138 & & 145 & 141 & \\
\hline Potassium (mmol/liter) & $3.6-5.1$ & 1.7 & 1.6 & & 3.4 & 4.0 & \\
\hline Chloride (mmol/liter) & 98-107 & 99 & & & & 111 & \\
\hline Calcium (mmol/l) & $2.20-2.65$ & 2.24 & & & 2.00 & 1.94 & \\
\hline Creatine kinase (U/l) & $<170$ & 2,372 & 1,742 & 1,439 & 6,411 & 7,750 & 5,327 \\
\hline Myoglobine (ng/ml) & $25-58$ & & & & 2911 & & 711 \\
\hline \multicolumn{8}{|l|}{ Hormones } \\
\hline $\mathrm{TSH}(\mu \mathrm{U} / \mathrm{ml})$ & $0.27-4.2$ & 0.521 & & & & & \\
\hline fT3 (pmol/l) & $3.13-6.76$ & 4.55 & & & & & \\
\hline fT4 (pmol/1) & $11.6-24.6$ & 21.1 & & & & & \\
\hline Aldosterone basal level (pmol/l) & $69-634$ & & & & & & 67 \\
\hline Renine $(\mathrm{pg} / \mathrm{ml})$ & $3-22$ & & & & & & 1.5 \\
\hline Cortisol (nmol/l) & $133-537$ & & & & & & 601 \\
\hline
\end{tabular}

Author contributions MW: acquisition and analysis of data, drafting the manuscript; AM and DC: acquisition and analysis of data, revising the manuscript; AS: revising the manuscript, analysis of data, study supervision.

Funding This research did not receive any specific grant from funding agencies in the public, commercial, or not-for-profit sectors.

\section{Compliance with ethical standards}

Conflicts of interest M Wittstock reports honoraria for presentations/ lectures/consultancies or advisory boards from Bristol-Myers Squibb, Daiichi Sankyo, Bayer Vital and from Boehringer Ingelheim. Allessandro Mele and Dabid Cantré declare that they have no conflict of interests. A Storch has received funding from the Deutsche Forschungsgemeinschaft (DFG) and the Helmholtz-Association. He received honoraria for presentations/lectures/consultancies or advisory boards from AbbVie, Bayer Healthcare, Bial, GKC, Grünenthal, UCB, Zambon, AbbVie, TEVA, Lundbeck, and UCB Pharma, outside the submitted work. He has served on the editorial boards of Stem Cells and Stem Cells International.

Ethical approval All procedures performed were in accordance with the ethical standards of the institutional committee.

Informed consent The patient gave her informed consent for this report.

Open Access This article is licensed under a Creative Commons Attribution 4.0 International License, which permits use, sharing, adaptation, distribution and reproduction in any medium or format, as long as you give appropriate credit to the original author(s) and the source, provide a link to the Creative Commons licence, and indicate if changes were made. The images or other third party material in this article are included in the article's Creative Commons licence, unless indicated otherwise in a credit line to the material. If material is not included in the article's Creative Commons licence and your intended use is not permitted by statutory regulation or exceeds the permitted use, you will need to obtain permission directly from the copyright holder. To view a copy of this licence, visit http://creativecommons. org/licenses/by/4.0/.

\section{References}

1. Edelmann ER, Butala NM, Avery LL, Lundquist AL, Dighe AS (2020) Case 30-2020: A 54-year-old man with sudden cardiac arrest. New Engl J Med 383(13):1263-2127

2. Kato H, Kanaoka M, Yano S, Kobayashi M (1995) 3-Monoglucuronyl-glycerhetinic acid is a major metabolite that causes licorice-induced pseudoaldosteronism. J Clin Endocrinol Metab 80:1929-1933

3. Munford E, Unwin RJ, Walsh SB (2019) Liquorice, Liddle, Bartter or Gitelmann - how to differentiate? Nephrol Dial Transplant 34:38-39

4. Rong HE, Guo WJ, She F, Miao GB, Liu F, Xue YJ, Liu YW, Wang HT, Zhang P (2018) A rare case of hypokalemia-induced rhabdomyolyis. J Geriatr Cardiol 15:321-324

5. Attout H, Randriajohany A, Josse F, Appavoupoule V, Thirapathi Y. Tetraparesis with major hypokalaemia and rhabdomyolysis induced by chronic liquorice ingestion. Eur $\mathrm{J}$ of Case Reports in Internal Med 2020; 7; DOI: https://doi.org/10.12890/2020_00137 5 . 